\title{
Utilization of Banana (Musa acuminata) Pseudostem for Biscuit Making
}

\author{
${ }^{a}$ Bunty Maskey*, ${ }^{a}$ Pradeep Sangroula, ${ }^{a}$ Nabindra Kumar Shrestha \\ ${ }^{a}$ Central Department of Food Technology, Institute of Science and Technology, Tribhuvan University, Dharan, Nepal \\ *Corresponding email: bunty.maskey@cdft.tu.edu.np
}

\begin{abstract}
The aim of this research was to utilize banana pseudostem powder as a functional replacement ingredient for wheat flour in the production of biscuit. In this study, D-optimal mixture design was employed and five different formulations were obtained. The biscuits were prepared by partially replacing wheat flour with banana pseudostem powder from 0 $10 \%$ and investigated for sensory and quality attributes. The biscuits were subjected to sensory evaluation by ten semi-trained panelists for consumer acceptability. The data obtained were statistically analyzed using two-way ANOVA (no blocking) at 5\% level of significance. From the mean sensory scores, 2.5 parts pseudostem incorporation was selected as the best formulation and subjected for further proximate analysis. The calcium, potassium, sodium, ash, fibre and fat contents were found to be higher in banana pseudostem incorporated biscuit than wheat flour biscuit.
\end{abstract}

\begin{tabular}{l}
\multicolumn{1}{c}{ Article Info } \\
\hline Article history: \\
Received date: June 132019 \\
Accepted date: 30 July 2020 \\
\hline \\
Keywords: \\
Banana pseudostem \\
biscuit \\
sensory evaluation \\
proximate analysis \\
\end{tabular}

\section{Introduction}

Biscuits are ready to eat, convenient and inexpensive food products containing digestive and dietary principles of vital importance (Agarwal, 1990). Biscuits are popular due to low cost, good nutritional quality and availability in different varieties, varied taste, easy availability and longer shelf life (Sudha et al., 2007). The baked products have about 6-7\% proteins. Biscuits owing to their long shelf life are considered useful for nutritional enrichment in feeding program (Agarwal, 1990).

The stem of the banana plant, which is also called pseudostem produces a single bunch of bananas before dying and is replaced by a new pseudostem (Anhwange et al., 2009). This crop generates a large amount of residue, due to the fact that each plant produces only one bunch of bananas. After the harvest, the bare pseudostem is cut and usually left on the plantation or burned, which could ultimately cause environment issues (Cordeiro et al., 2004). Thus, the utilization of the banana waste pseudostems has gained more attention in recent years. The banana pseudostem has been used as material for paper, furniture and forage (Buragohain et al., 2010; Umaz et al., 2005). Moreover, it has been reported that these banana waste materials are rich in minerals and nutrients, especially dietary fibre (Aziz et al., 2011). The exploitation of waste banana pseudostems into products could significantly benefit the environment and increase its economic value. The banana pseudostem could potentially be used more in food rather than in other industries (Tiroutchelvame et al., 2019). Pseudostem have low glycemic index and have a high content of dietary fibre and antioxidant which is good for diabetes (Bhaskar et al., 2011). Supplementation has been used to enhance fibre content of foods and has been focused on biscuits, cookies, crackers and other cereal-based products (Ayo-Omogie \& Odekunle, 2017; Dhingra et al., 2012).

Traditional biscuits are claimed to lack other essential nutritional components such as dietary fibre, vitamins and minerals which are lost during wheat flour refinement (Asif-Ul-Alam et al., 2014). Flour blends with high dietary fibre flour have been commonly applied in the bakery industry to reduce the utilization of large quantities of flour as well as to increase the dietary fibre intake of the consumer (Ho et al., 2017). Moreover, the diameter and thickness of cookies gradually increase as the level of flour 
substitution (Hussain et al., 2006; Masoodi \& Bashir, 2012) while the spread ratio gradually decrease (Ganorkar \& Jain, 2014).

The significance of the study is to utilize banana pseudostem as potential nutritious food which enhances the overall property of biscuit both functionally and nutritionally. Therefore, this work was carried out for the preparation of different biscuit formulations with different proportion of banana pseudostem powder with wheat flour.

\section{Materials and Methods}

\subsection{Material collection}

White wheat flour, sugar, salt, vanaspati ghee, skim milk powder (SMP) and baking powder was used for biscuit making. A common variety of fresh banana (Musa acuminata) pseudostem, after harvesting banana, was used. High density polyethylene (HDPE) of 50 micron was used for the packaging of the biscuit.

\subsection{Methods}

\subsubsection{Formulation of recipe}

Design Expert v7.1.5 software was used to create the recipe. D-optimal mixture design was used to formulate the recipe. The independent variable for the experiment is concentration of banana pseudostem powder used to make biscuit. The biscuit was made as per the recipe formulation done and coded name A, B, $\mathrm{C}, \mathrm{D}$ and $\mathrm{E}$ were given to each recipe. Composite biscuit was of soft dough type. The recipe formulation for the banana pseudostem incorporated biscuit was carried out as given in Table 1.

Table 1: Recipe formulation for biscuit.

\begin{tabular}{llllll}
\hline Ingredient & $\mathrm{A}$ & $\mathrm{B}$ & $\mathrm{C}$ & $\mathrm{D}$ & $\mathrm{E}$ \\
\hline $\begin{array}{l}\text { Wheat flour } \\
\text { Banana }\end{array}$ & 100 & 97.5 & 95 & 92.5 & 90 \\
pseudostem & & & & & \\
powder & 0 & 2.5 & 5 & 7.5 & 10 \\
Sugar & 40 & 40 & 40 & 40 & 40 \\
Fat & 35 & 35 & 35 & 35 & 35 \\
SMP & 6 & 6 & 6 & 6 & 6 \\
Baking powder & 2.22 & 2.22 & 2.22 & 2.22 & 2.22 \\
Salt & 0.3 & 0.3 & 0.3 & 0.3 & 0.3 \\
\hline
\end{tabular}

\subsubsection{Preparation of banana pseudostem powder}

The banana pseudostem was first cleaned to remove the outer sheath. After removing the outer sheath, the inside found central core was washed and sliced using a stainless-steel knife. The slices were then soaked in a solution of $0.2 \%$ concentration of potassium metabisulphate (KMS) for $10 \mathrm{~min}$ in order to control browning. They were then dried in a cabinet dryer at $60^{\circ} \mathrm{C}$ temperature for $48 \mathrm{~h}$, from an initial moisture content of $90 \%$ to final moisture content of $6 \%(\mathrm{wb})$ (Ambrose \& Naik, 2016). The dried samples were powdered in a laboratory pulverizer to a fineness that $90 \%$ of the powder passed through 400-micron sieve. The flour obtained was packed in Aluminium foil pouches, sealed and stored at room temperature (Ambrose \& Naik, 2016).

\subsubsection{Preparation of banana pseudostem incorporated biscuit}

As per formulation (Table 1), 500g batch was prepared for each. The calculated amount of fat and sugar powder were firstly creamed; salt was dissolved in water and added to the prepared cream mixture. As creaming process was continued, composite flour and baking powder were added and stirred well together. The full prepared dough was sheeted 5-6 mm thick and a dye of $7 \mathrm{~mm}$ thickness and $65 \mathrm{~mm}$ diameter was used to obtain uniform biscuit shape. The formed biscuits were baked at $200^{\circ} \mathrm{C}$ for $15 \mathrm{~min}$. After cooling to about $35^{\circ} \mathrm{C}$, the biscuits were packed in HDPE packages (Smith, 1972).

\subsection{Analysis of raw materials and product}

\subsubsection{Physical parameter analysis}

a) Spread ratio: The spread ratio of the biscuit was determined by using the formula as per AOAC (2005).

$$
\text { Spread ratio }=\frac{\text { Diameter }(\mathrm{mm})}{\text { Thickness }(\mathrm{mm})}
$$

where, diameter was measured in $\mathrm{mm}$ by Vernier caliper and thickness was measured in $\mathrm{mm}$ by screw gauge.

b) Volume: Volume of the biscuit was determined by the area of biscuit multiplied by thickness as per AOAC (2005).

$$
\text { Volume }\left(\mathrm{cm}^{3}\right)=\frac{\pi d^{2} t}{4}
$$

where, $\mathrm{t}=$ Average thickness of biscuit $(\mathrm{mm})$

$$
\mathrm{d}=\text { Diameter of biscuit }(\mathrm{mm})
$$

c) Density: Density of biscuit was obtained by the ratio of mass to the volume of the biscuit as per AOAC (2005). The volume was measured by rapeseed displacement method. 


$$
\operatorname{Density}\left(\mathrm{g} / \mathrm{cm}^{3}\right)=\frac{\operatorname{Mass}(\mathrm{g})}{\operatorname{Volume}\left(\mathrm{cm}^{3}\right)}
$$

\subsubsection{Physicochemical analysis}

a) Moisture content: Moisture content of the sample was determined by heating in an oven at $100 \pm 5^{\circ} \mathrm{C}$ to get constant weight (Ranganna, 1986).

b) Crude fat: Crude fat content of the samples was determined by solvent extraction method using Soxhlet apparatus and solvent petroleum ether (Ranganna, 1986).

c) Crude protein: Crude protein content of the samples was determined indirectly by measuring total nitrogen content by micro Kjeldahl method. Factor 6.25 was used to convert the nitrogen content to crude protein (Ranganna, 1986).

d) Crude fibre: Crude fibre content of the samples was determined by the method given by (Ranganna, 1986).

e) Total ash: Total ash content of the samples was determined by following the method given by (Rananna, 1986) using muffle furnace.

f) Carbohydrate: The carbohydrate content of the sample was determined by difference method.

Carbohydrate $(\%)=100-($ protein + fat + ash + crude fibre)

g) Potassium content: The potassium content of the sample was determined by flame photometer as per KC \& Rai (2007). Biscuit ash solution is atomized in an oxy-hydrogen or oxyacetylene flame. The flame excites atoms of potassium causing them to emit radiations of specific wavelengths. The amount of radiation emitted is measured by the emission flame photometer (potassium $768 \mathrm{~nm}$ ). Under standard conditions, the amount of emission is proportional to the concentration of potassium in the sample solution.

h) Sodium content: The sodium content of the sample was determined by flame photometer as per AOAC (2005).

i) Calcium content: The calcium content of the sample was determined by flame photometer as per AOAC (2005).

\subsection{Sensory analysis}

The sensory analysis for overall quality was carried out with ten semi-trained panelists. The parameters for sensory evaluation were texture, crispiness, color, taste, flavour and overall acceptability. Sensory evaluation was performed according to the 9-point hedonic scale (Ranganna, 1986).

\subsection{Statistical analysis}

The obtained data was analyzed statistically by Genstat Discovery Edition 3, for Analysis of Variance (ANOVA) at 5\% level of significance. The data obtained from proximate analysis and sensory evaluations were subjected to two-way Analysis of Variance. Means are separated whether they are significant or not by using Least Significant Difference (LSD) method.

\section{Results and Discussion}

\subsection{Proximate composition}

Wheat flour and banana pseudostem powder were analyzed for proximate components. The results of analysis of wheat flour and banana pseudostem powder are tabulated in Table 2 . The proximate composition of SMP from the label provided in the packet is given in Table 3.

Table 2: Proximate composition of wheat flour and banana pseudostem powder

\begin{tabular}{lll}
\hline Proximate Composition & $\begin{array}{l}\text { Wheat } \\
\text { Flour* }\end{array}$ & $\begin{array}{l}\text { Pseudostem } \\
\text { Powder* }\end{array}$ \\
\hline Moisture content (\%) & $12.35 \pm 0.25$ & $6.2 \pm 0.15$ \\
Crude protein (\% DM) & $10.2 \pm 0.12$ & $3.6 \pm 0.01$ \\
Crude fat (\% DM) & $1.55 \pm 0.02$ & $1.8 \pm 0.02$ \\
Crude fibre (\% DM) & $0.61 \pm 0.01$ & $13.3 \pm 0.03$ \\
Total ash (\% DM) & $0.57 \pm 1.23$ & $12.3 \pm 0.01$ \\
Carbohydrate (\% DM) & $87.11 \pm 0.45$ & $62.8 \pm 0.25$ \\
Gluten content (\% DM) & $8.1 \pm 0.25$ & - \\
Calcium (mg/100g DM) & $34 \pm 0.15$ & $318 \pm 0.03$ \\
Potassium(mg/100g DM) & $126 \pm 0.35$ & $680 \pm 0.20$ \\
Sodium (mg/100g DM) & $2 \pm 0.01$ & $104 \pm 0.01$ \\
\hline \multicolumn{4}{c}{$\%$ DM g/100 g, on a dry matter basis } \\
$\quad *$ Values are the means of three determinations \pm \\
standard deviations. Figures in the parenthesis are standard \\
deviations.
\end{tabular}

Table 3: Proximate Composition of SMP (per 100g).

\begin{tabular}{ll}
\hline Component & SMP \\
\hline Milk protein & $34 \mathrm{~g}$ \\
Total carbohydrate & $53 \mathrm{~g}$ \\
Fat & $1 \mathrm{~g}$ \\
Ash & $7 \mathrm{~g}$ \\
\hline
\end{tabular}

The moisture content of the banana pseudostem powder was found to be $6.2 \%$. Tiroutchelvame et al. 
(2019) reported lower moisture content in dried banana pseudostem. The reason for this difference might be attributed to species, size of pseudostem pieces and drying conditions. The protein content was found to be $3.6 \%$ and this was similar to the result obtained by Aziz et al. (2011). The fat content was found to be $1.8 \%$ which was similar to the finding reported by Bhaskar et al. (2012). The ash content of pseudostem powder in the present study $(12.30 \%)$ is higher than ash content of wheat flour $(0.57 \%)$. The high ash content is correlated with the presence of a high mineral content and the banana pseudostem has an abundant mineral composition (Cordeiro et al., 2004; Mukhopadhyay et al., 2008). The crude fibre of the banana pseudostem powder was found to be $13.3 \%$ which was similar result obtained by Tiroutchelvame et al. (2019).

\subsection{Influence of pseudostem powder on physical parameters of biscuits}

Physical characteristics of biscuits such as thickness, diameter, spread ratio, weight, volume and density were affected by the substitution increment of the level of pseudostem powder which is presented in Table 4. The results indicated that diameter and thickness of biscuit were slightly increased with increasing substitution percentage of pseudostem flour. 10 parts pseudostem flour incorporated biscuit revealed the maximum diameter and thickness $(62.14 \mathrm{~mm}$ and $6.56 \mathrm{~mm}$ respectively). Hussain et al. (2006) found that the diameter and thickness of cookies showed gradually increase as the level of flour substitution increases. Moreover, the results of spread ratio ofbiscuit revealed a reduction in spread ratio from 9.85 to 9.47. These results are on the line with the findings of Ganorkar \& Jain (2014) who reported that the reduction in spread ratio might be due to increase in dietary fibre and protein percentage with increasing level of pseudostem flour because dietary fibre and protein has more water-binding power.

\subsection{Sensory analysis of banana pseudostem incorporated biscuit}

Statistical analysis of the sensory scores was obtained from 10 semi-trained panelists using 9- point hedonic rating scale ( $9=$ like extremely, $1=$ dislike extremely) for composite biscuit formulations. Sensory analysis was performed with the aid of different panelists evaluating texture, crispiness, color, taste, flavour and overall acceptability of banana pseudostem powder incorporated biscuit. The mean sensory score is presented in Table 5 .

The mean sensory score for texture of sample B was found to be 7.7, which was the highest score of all the biscuit formulations. Statistical analysis showed that the partial substitution of wheat flour with banana pseudostem flour had significant effect $(\mathrm{p}<0.05)$ on the texture. Sample B got highest score, which was not significantly different with sample A.

Table 4: Physical parameters of banana pseudostem incorporated biscuits.

\begin{tabular}{cllllll}
\hline Samples & $\begin{array}{l}\text { Thickness } \\
(\mathrm{mm})\end{array}$ & $\begin{array}{l}\text { Diameter } \\
(\mathrm{mm})\end{array}$ & $\begin{array}{l}\text { Spread } \\
\text { ratio }\end{array}$ & $\begin{array}{l}\text { Weight } \\
(\mathrm{g})\end{array}$ & $\begin{array}{l}\text { Volume } \\
\left(\mathrm{cm}^{3}\right)\end{array}$ & $\begin{array}{l}\text { Density } \\
\left(\mathrm{g} / \mathrm{cm}^{3}\right)\end{array}$ \\
\hline $\mathrm{A}$ & $6.12^{\mathrm{a}} \pm 0.1$ & $60.30^{\mathrm{a}} \pm 0.2$ & $9.85^{\mathrm{e}} \pm 0.15$ & $14.09^{\mathrm{e}} \pm 0.2$ & $17.48^{\mathrm{a}} \pm 01$ & $0.806^{\mathrm{e}} \pm 0.15$ \\
$\mathrm{~B}$ & $6.18^{\mathrm{b}} \pm 0.2$ & $60.78^{\mathrm{ab}} \pm 0.1$ & $9.83^{\mathrm{d}} \pm 0.15$ & $13.92^{\mathrm{d}} \pm 0.3$ & $17.92^{\mathrm{b}} \pm 0.2$ & $0.776^{\mathrm{d}} \pm 0.25$ \\
$\mathrm{C}$ & $6.29^{\mathrm{c}} \pm 0.3$ & $61.30^{\mathrm{ab}} \pm 0.1$ & $9.74^{\mathrm{c}} \pm 0.2$ & $13.58^{\mathrm{c}} \pm 0.2$ & $18.55^{\mathrm{c}} \pm 0.1$ & $0.731^{\mathrm{c}} \pm 0.15$ \\
$\mathrm{D}$ & $6.42^{\mathrm{d}} \pm 0.1$ & $61.96^{\mathrm{ab}} \pm 0.1$ & $9.65^{\mathrm{b}} \pm 0.1$ & $13.14^{\mathrm{b}} \pm 0.3$ & $19.34^{\mathrm{d}} \pm 0.2$ & $0.679^{\mathrm{b}} \pm 0.26$ \\
$\mathrm{E}$ & $6.56^{\mathrm{e}} \pm 0.2$ & $62.14^{\mathrm{b}} \pm 0.1$ & $9.47^{\mathrm{a}} \pm 0.15$ & $12.86^{\mathrm{a}} \pm 0.2$ & $19.88^{\mathrm{e}} \pm 0.1$ & $0.646^{\mathrm{a}} \pm 0.15$ \\
\hline
\end{tabular}

Table 5: Mean sensory scores of banana pseudostem incorporated biscuits.

\begin{tabular}{clllllc}
\hline Sample code & Texture & Crispness & Color & Taste & Flavor & Overall acceptability \\
\hline A & $7.0^{\mathrm{ab}} \pm 0$ & $7.4^{\mathrm{b}} \pm 1.07$ & $6.5^{\mathrm{b}} \pm 1.08$ & $7.3^{\mathrm{c}} \pm 0.82$ & $7.0^{\mathrm{ab}} \pm 0.94$ & $6.9^{\mathrm{ab}} \pm 1.28$ \\
B & $7.7^{\mathrm{b}} \pm 0.67$ & $7.3^{\mathrm{b}} \pm 0.95$ & $7.0^{\mathrm{c}} \pm 0.82$ & $7.6^{\mathrm{c}} \pm 0.51$ & $7.5^{\mathrm{b}} \pm 0.52$ & $7.5^{\mathrm{b}} \pm 0.63$ \\
C & $6.7^{\mathrm{ab}} \pm 0.67$ & $7.0^{\mathrm{ab}} \pm 0.94$ & $6.9^{\mathrm{bc}} \pm 0.56$ & $6.9^{\mathrm{bc}} \pm 0.73$ & $6.3^{\mathrm{a}} \pm 0.94$ & $6.8^{\mathrm{ab}} \pm 0.63$ \\
D & $6.1^{\mathrm{a}} \pm 0.97$ & $6.4^{\mathrm{a}} \pm 0.96$ & $6.7^{\mathrm{b}} \pm 1.25$ & $6.3^{\mathrm{ab}} \pm 1.05$ & $6.8^{\mathrm{ab}} \pm 1.23$ & $6.6^{\mathrm{ab}} \pm 1.07$ \\
E & $6.4^{\mathrm{a}} \pm 0.96$ & $6.4^{\mathrm{a}} \pm 0.84$ & $5.6^{\mathrm{a}} \pm 0.96$ & $6.0^{\mathrm{a}} \pm 0.83$ & $6.4^{\mathrm{a}} \pm 1.07$ & $6.0^{\mathrm{a}} \pm 0.66$ \\
\hline
\end{tabular}


Sample B showed firm texture, and no cracks, which might be due to adequate amount of gluten development (Ho et al., 2017).

Statistical analysis showed that partial substitution of wheat flour with pseudostem flour had significant effect $(p<0.05)$ on the crispness. Sample A was significantly different to other samples but similar to sample B. The sample A got highest score while E rank lowest score because incorporation of high level of pseudostem flour depresses the water holding capacity (Ho et al., 2017).

The mean sensory score for color of sample B was found to be 7 and was the highest of all other biscuit formulations which was significantly different $(p<0.05)$ from other samples. Statistical analysis showed that the partial substitution of wheat flour with pseudostem flour has significant effect $(\mathrm{p}<0.05)$ on the color. The sample B got the higher score may be due to the appropriate amount of pseudostem powder (Masoodi \& Bashir, 2012).

Statistical analysis showed that the partial substitution of wheat flour with pseudostem flour had significant effect $(\mathrm{p}<0.05)$ on the taste. Sample B was found to be scoring highest in taste as compared to other samples with incorporation of pseudostem flour. This may be due to development of bitterness in higher substitution of pseudostem flour (Asif-Ul-Alam et al., 2014). However, it is found to be similar to sample C. Sample E is the lowest scoring formulations of all which indicates that higher amount of pseudostem powder in the formulations could lower the acceptability of the product.

The mean sensory score for flavor of sample B was 7.5 and was the highest score scored among the different formulations. The lowest mean sensory score was of sample C. Samples D, E, F, G, and H were not significantly different to sample $\mathrm{C}$ in flavor. The lower sensory scores for other formulations in comparison to Sample B may be due to the fact that incorporation of more pseudostem flour may develop undesirable flavor changes accounting to increase in ash content and compositional attributes (Ayo-Omogie \& Odekunle, 2017). Statistical analysis showed that the partial substitution of wheat flour with pseudostem powder had significant effect $(\mathrm{p}<0.05)$ on the flavor.

Sample B scored highest in overall acceptability of the sensory conducted among the panellists, which might be due to good texture as adequate amount of gluten formation was possible in such composition (Ho et al., 2017). Statistical analysis data showed that the partial substitution of pseudostem flour in samples showed significant difference $(\mathrm{p}<0.05)$ in overall acceptability of samples. Sample E showed lowest score in overall acceptability which could be as a result of highest amount of pseudostem flour incorporated in it. Similarly, not too much amount of pseudostem flour, but adequate enough to provide good flavour, better swelling power and solubility capacity might have provided good mouth feel in sample B.

\subsection{Proximate composition of optimized product}

The composition of the best product and the control biscuit from chemical analysis is given in the Table 6.

Table 6: Composition of control and banana pseudostem incorporated biscuit.

\begin{tabular}{lll}
\hline Proximate composition & $\begin{array}{l}\text { Control } \\
\text { biscuit }\end{array}$ & $\begin{array}{l}\text { Banana } \\
\text { biscuit }\end{array}$ \\
\hline Moisture content (\%) & $2.62 \pm 0.18$ & $2.54 \pm 0.15$ \\
Crude protein (\% DM) & $6.7 \pm 0.12$ & $5.8 \pm 0.19$ \\
Crude fat (\% DM) & $16.26 \pm 0.25$ & $18.6 \pm 0.19$ \\
Crude fibre (\% DM) & $1.1 \pm 0.01$ & $1.7 \pm 0.02$ \\
Total ash (\% DM) & $2 \pm 0.02$ & $2.25 \pm 0.08$ \\
Calcium (mg/100g DM) & $52.3 \pm 0.13$ & $57.7 \pm 0.21$ \\
Potassium (mg/100g DM) & $210.4 \pm 0.30$ & $274.2 \pm 0.35$ \\
Sodium (mg/100g DM) & $28.6 \pm 0.18$ & $95.9 \pm 0.23$ \\
\hline
\end{tabular}

$\% D M=g / 100 g$, on a dry matter basis

The moisture content was found to be $2.62 \%$ in control biscuit and $2.54 \%$ in banana pseudostem incorporated biscuit. This variation in moisture content may be due to low water holding capacity of banana pseudostem flour (Ho et al., 2017). The protein content of biscuits was found to be $5.8 \%$ in banana pseudostem incorporated biscuit and $6.7 \%$ in control. The low protein content in the banana pseudostem biscuit is because of the fact that initial protein content of wheat flour $(10.2 \%)$ is higher in comparison to that of banana pseudostem flour (3.6\%), which impacts the overall protein content of the product (Aziz et al., 2011). The fat content of banana pseudostem incorporated biscuit $(18.6 \%)$ was higher than control $(16.26 \%)$. This was probably due to the oil retention ability of pseudostem flour during baking process. Higher oil retention improves the mouth feel and retains the flavor of the biscuits (Ganorkar \& Jain, 2014). Banana pseudostem incorporated biscuit showed an increase in the fibre content as banana pseudostem are found to be one of the richest sources of crude fibre (Cordeiro et al., 2004). 
The biscuits showed an increase in ash content in banana pseudostem incorporation (2.25\%) as compared to control sample (2\%). The higher level of minerals is demonstrated by higher level of calcium $(57.7 \mathrm{mg} / 100 \mathrm{~g})$, potassium $(274.2 \mathrm{mg} / 100 \mathrm{~g})$ and sodium $(95.9 \mathrm{mg} / 100 \mathrm{~g})$ in banana pseudostem incorporated biscuit as banana pseudostem contains a lot of minerals confirmed by its higher ash content (Aziz et al., 2011).

\section{Conclusions}

Based on the findings in the present study, it can be concluded that the banana pseudostem incorporated biscuit can be produced by substituting wheat flour with banana pseudostem powder at a level of 2.5 parts, with no adverse effect on sensory quality. The proximate analysis showed that the nutritional quality of the biscuit is enhanced mainly in the case of crude fibre and minerals content. So, the addition of fibre to biscuit increases the dietary fibre intake and decreases the caloric density of baked goods.

\section{Acknowledgments}

We would like to express our humble gratitude to Central Department of Food Technology and all the staffs of Central Campus of Technology for their cooperation and support.

\section{Conflicts of Interest}

The authors declare no conflicts of interest.

\section{Funding}

This research received no external funding.

\section{References}

Agarwal, S. R. (1990). Prospects of small scale biscuit industry in ninetics. Indian Food Industry. 9, 19-21.

Ambrose, C. P., \& Naik, R. (2016). Development of a process for utilization of banana waste. International Journal of Research in Applied, Natural and Social Sciences. 4(6), 83-88.

Anhwange, B. A., Ugye, T. J., \& Nyiaatagher, T. D. (2009). Chemical composition of Musa sapientum (banana) peels. Electronic Journal of Environmental, Agricultural and Food Chemistry, 8(6), 437-442.
AOAC. (2005). "Official Methods of Analysis of the Association of Official Analytical Chemists" (18th ed.). Arlington, Virgina, USA.

Asif-Ul-Alam, S. M., Islam, M. Z., Hoque, M. M., \& Monalisa, K. (2014). Effects of drying on the physicochemical and functional properties of green banana (Musa sapientum) flour and development of baked product. American Journal of Food Science and Technology, 2(4), 128-133.

Ayo-Omogie, H. N., \& Odekunle, O. Y. (2017). Substituting Wheat Flour with Banana Flour: Effects on the Quality Attributes of Doughnut and Cookies. Applied Tropical Agriculture, 22(2), 134137.

Aziz, N. A. A., Ho, L. H., Azahari, B., Bhat, R., Cheng, L. H., \& Ibrahim, M. N. M. (2011). Chemical and functional properties of the native banana (Musa acuminate $\mathrm{x}$ balbisiana Colla cv. Awak) pseudostem and pseudo-stem tender core flours. Food Chemistry. 128, 748-753.

Bhaskar, J. J., Chilkunda, N. D., \& Salimath, P. V. (2012). Banana (Musa sp. var. elakki bale) flower and pseudostem: dietary fiber and associated antioxidant capacity. Journal of agricultural and food chemistry, 60(1), 427-432.

Bhaskar, J. J., Shobha, M. S., Sambaiah, K., \& Salimath, P. V. (2011). Beneficial effects of banana (Musa sp. var. elakki bale) flower and pseudostem on hyperglycemia and advanced glycation endproducts (AGEs) in streptozotocin-induced diabetic rats. J. Physiol. Biochem. 67(3), 415-425.

Buragohain, R., Kalita, G., \& Sarma, K. (2010). Nutritional significance of banana as swine feed. Indian Veterinary Journal, 87(3), 301-302.

Cordeiro, N., Belgacem, M. N., Torres, I. C., \& Moura, J. C. V. P. (2004). Chemical composition and pulping of banana pseudo-stems. Industrial Crops and Products, 19(2), 147-154.

Dhingra, D., Michael, M., Rajput, H., \& Patil, R. T. (2012). Dietary fibre in foods: a review. Journal of Food Science and Technology. 49 (3), 255-266.

Ganorkar, P. M., \& Jain, R. K. (2014). Effect of flaxseed incorporation on physical, sensorial, textural and chemical attributes of cookies. International Food Research Journal, 21(4). 
Ho, L. H., Tan, T. C., Aziz, N. A. A., \& Muhamad, N. (2017). Physical and functional properties of banana pseudostem flour and its effect on the quality (texture and microstructure) of formulated bread. Journal of Agrobiotechnology, 8(1), 1-12.

Hussain, S., Anjum, F. M., Butt, M. S., Khan, M. I., \& Asghar, A. (2006). Physical and sensoric attributes of flaxseed flour supplemented cookies. Turkish Journal of Biology, 30(2), 87-92.

KC, J. B., \& Rai, B. K. (2007). "Basic Food Analysis Handbook" (1st ed.). Prompt Printers Pvt. Ltd. Kathmandu, Nepal.

Masoodi, L., \& Bashir, V. (2012). Fortification of biscuit with flaxseed: biscuit production and quality evaluation. IOSR Journal of Environmental Science, Toxicology and Food Technology, 1(5), 06-09.

Mukhopadhyay, S., Fangueiro, R., Arpac, Y., \& Şentürk, Ü. (2008). Banana fibers-variability and fracture behaviour. Journal of Engineered Fibers and Fabrics, $3(2)$, doi:10.1177/155892500800300207

Ranganna, S. (1986). Manual analysis of fruits and vegetable products. Tata McGraw Hill Publication Co., New Delhi.

Smith, W. H. (1972). Biscuits, Crackers and Cookies (1st ed.). Applied science publishers, London.

Sudha, M. L., Vetrimani, R., \& Leelavathi, K. (2007). Influence of fibre from different cereals on the rheological characteristics of wheat flour dough and on biscuit quality. Food chemistry, 100(4), 13651370 .

Tiroutchelvame, D., Pragalyaashree, M. M., \& Peter, D. (2019). Process Development for the Value Addition of Banana Central Core (Pseudo Stem). International Journal of Recent Technology and Engineering. 8(4), 1055-1060.

Umaz, S., Kalpana, S., Sathiamoorthy, S., \& Kumar, V. (2005). Evaluation of commercial cultivars of banana. Plant Genetic Resources Newsletter. 142, 29-35. 